American Journal of Agricultural and Biological Sciences 2 (2): 99-105, 2007

ISSN 1557-4989

(C) 2007 Science Publications

\title{
Towards Growing Bario Rice on Lowland Soils: A Preliminary Nitrogen and Potassium Fertilization Trial
}

\author{
Muyang Tawie Sulok Kevin, Osumanu Haruna Ahmed, Wan Yahaya Wan Asrina, Amartalingam Rajan \\ and Mohamad Ahzam \\ Department of Crop Science, Faculty of Agriculture and Food Sciences \\ Universiti Putra Malaysia Bintulu Campus, Sarawak \\ 97008 Bintulu, Sarawak Malaysia
}

\begin{abstract}
A pot study was carried with the following objectives: (i) To investigate $\mathrm{N}$ and $\mathrm{K}$ uptake of Bario rice on Bekenu series (Tipik Tualemkuts), and (ii) To investigate $\mathrm{N}$ and $\mathrm{K}$ use efficiency of Bario rice on Bekenu series. Treatments evaluated were: (i) Bario rice under fertilized condition (T1), and (ii) Bario rice under unfertilized condition (T0). The experiment was conducted in a glasshouse at Universiti Putra Malaysia Bintulu Campus, Sarawak, Malaysia. Altogether 18 pots were used. The experimental design was completely randomized design (CRD) with 9 replications. Nitrogen and $\mathrm{K}$ were applied in the forms of urea $(46 \% \mathrm{~N})$ and muriate of potash $\left(60 \% \mathrm{~K}_{2} \mathrm{O}\right)$ at the rates of $0.52 \mathrm{~g} \mathrm{~N}$ $\mathrm{g}$ and $0.60 \mathrm{~g} \mathrm{~K}_{2} \mathrm{O}$ per pot respectively at specific times. The fertilizers applications were done 20 and 45 days after seeding (for T1 only). However, $\mathrm{P}$ was applied to T1 pots only in the form of Christmas Island Rock Phosphate $\left(36 \% \mathrm{P}_{2} \mathrm{O}_{5}\right)$ at a rate of $0.54 \mathrm{~g} \mathrm{P}_{2} \mathrm{O}_{5}$ per pot. At 65 days after planting, the Bario rice plants were sampled and partitioned into roots and stem. Their dry weight, N, and $\mathrm{K}$ concentrations determined using standard procedures. Soil sampling was done before and after fertilization stages. Soil total $\mathrm{N}$ was determined using the Kjeldahl method while exchangeable K, Ca, $\mathrm{Na}$, and $\mathrm{Mg}$ were extracted using the double acid method and their concentrations determined using atomic absorption spectrophotometry. Dry ashing method was used for the determination of $\mathrm{K}$, $\mathrm{Ca}$, $\mathrm{Na}$, and $\mathrm{Mg}$ concentrations in plant tissues while the Kjeldahl method was used to determine total $\mathrm{N}$ in plant tissues. The concentrations multiplied by the oven dried weight of roots and stem provided $\mathrm{N}, \mathrm{K}$, $\mathrm{Ca}, \mathrm{Na}$, and $\mathrm{Mg}$ uptake in these plant parts. The $\mathrm{N}$ and $\mathrm{K}$ use efficiency were then calculated using the subtraction method. With the exception of $\mathrm{Ca}$, urea and $\mathrm{KCl}$ (MOP) application significantly increased soil $\mathrm{N}, \mathrm{K}, \mathrm{Mg}$, and $\mathrm{Na}$ concentrations. Total dry weight for both stem and roots showed no significant difference under $\mathrm{T} 1$ and $\mathrm{T} 0$. Except for $\mathrm{Mg}$ concentration in stem and roots, $\mathrm{K}$ concentration in stem and that of $\mathrm{N}$ in roots were significantly higher under $\mathrm{T} 1$ than under $\mathrm{T} 0$. The other comparisons showed no significant difference. Due to $\mathrm{N}$ and $\mathrm{K}$ fertilization, there was significant increase in plant height and number of panicles under T1 compared to T0. Nitrogen, $\mathrm{K}, \mathrm{Na}$, and $\mathrm{Mg}$ uptake in stem were significantly higher for T1 than T0. However, those of roots were not significantly different. The overall $\mathrm{N}$ and $\mathrm{K}$ use-efficiency of the Bario rice were $9.90 \%$ and $4.23 \%$ respectively, and were considered low, indicating that rice grown within the time frame of this study did not efficiently utilize these nutrients. This was partly attributed to low $\mathrm{N}$ and $\mathrm{K}$ recovery during reduced condition and low organic matter status of Bekenu series as Bario rice is noted for being cultivated organically. Additionally, slow adaptation to inorganic fertilizers and sudden climatic change involved in this study cannot be ruled out as one of the reasons for the low efficiency because the rice is traditionally cultivated in the highlands of Sarawak, Malaysia. However, with appropriate fertilization and soil maintenance (through further research), Bekenu series could be used for Bario rice production. Probably supplementing inorganic fertilizers with organic ones may help to improve growth and development of this rice on Bekenu series. Future studies may consider mimicking or modifying the environment to suit Bario rice growth and development at lower elevations. Certainly, the quality of Bario rice at lower elevations should also be considered in future fertilization programmes or trials.
\end{abstract}

Key word: Bario rice, fertilizer trial, nitrogen, potassium, rice, Malaysia

\section{INTRODUCTION}

Rice is one of the most important cereal crops in the world and ranks second after wheat. The continuous growth in world rice production has further elevated its eminence as a staple, with importance equal to that of wheat. In many areas of the developing world, rice is gaining popularity as a preferred source of
Corresponding Author:

Osumanu Haruna Ahmed, Department of Crop Science, Faculty of Agriculture and Food Sciences, Universiti Putra Malaysia Bintulu Campus, Sarawak, Malaysia, Tel: (+6086855406, Fax: $+608685415$ 
caloric supply. For instance rice covers about 148 million hectares of the earth surface and the production has been estimated to be 522 tons in the world ${ }^{[1]}$. On an average basis, rice produces a higher grain yield than wheat or maize and can support more people per hectare of land.

In Malaysia, the area of rice production is not sufficient; as a result, rice such as Bario is grown in the highlands of Sarawak. Bario rice is produced by the Kelabit farmers in Sarawak. Bario Rice is regarded by the 'Orang Ulu' tribe and natives as the finest and best rice from the highlands of Sarawak. It is grown on cool climates at an elevation above 1,200 meters. According to the natives, the rice is only eaten by the Longhouse Chief on special occasion. Bario rice has long been regarded as one of the finest rice grains of the world. It is famous for its soft texture, fine and elongated grains with mild aromas and splendid taste. It is home-grown rice, planted and harvested entirely by hand using old and traditional methods. In the fertile valleys of the highlands rice is grown at 1200 meters above the sea level and irrigated by the cool and clean mountain streams. Bario rice is produced without the usage of pesticides and chemical fertilizers, probably due to logistics of transporting these materials to the highlands. Even if the pesticides and fertilizers get there, they are expensive for the local farmers to afford. Therefore Bario rice has all the attributes of organic rice with the added flavour and distinguished taste derived from the cool, pristine and unpolluted environments where it is grown. Bario rice is from the Adan variety and the market price ranges from RM 8 (US\$ 2.30) to RM 9 (US\$3.00) per kilogram. Even though the Bario rice is popular with good price in Sarawak, the optimum yield (potential yield) has not been attained. One of the reasons could be lack of adequate use of nutrients such as N, P, and K. Besides, the cultivation of this rice has not been tested on lowland acid soils such as Bekenu series commonly found in the tropics to enable wide cultivation to meet the current demand of the rice.

Since the rice cultivar is commonly planted in high hilly areas, this experiment will exposed it to the local Bintulu, Sarawak soil type such as the Bekenu series. The Bekenu series is a member of the Bekenu family which is fine loamy, siliceous, isohyperthermic, redyellow to yellow Tipik Tualemkuts [2]. It typifies the family and is developed over mixed sedimentary rocks. Soils of the Bekenu series are defined as being characterized by their deep, well drained profiles with brownish yellow to yellow subsoil colours dominating the subsoil. These soils have an argilic horizon with fine sandy clay loam textures and ECECclay of less than $24 \mathrm{cmol}(+) \mathrm{kg}^{-1}$ clay in all subhorizons (between 25 to $100 \mathrm{~cm}$ depth). They have weak medium to coarse subangular blocky and consistence is friable. In terms of suitability for agriculture, the Bekenu series has low fertility status and the terrain on which these soils occur are the main limiting factors for the use of these soils. However, with proper fertilization and soil conservation measures, a wide range of crops such as upland rice could be cultivated on these soils.

The objectives of this study were: (i) To investigate $\mathrm{N}$ and $\mathrm{K}$ uptake of Bario rice on Bekenu series, and (ii) To investigate $\mathrm{N}$ and $\mathrm{K}$ use-efficiency of Bario rice on Bekenu series.

\section{MATERIALS AND METHODS}

The experiment was a pot study and conducted in a glasshouse at the Universiti Putra Malaysia Bintulu Campus, Sarawak. The type of soil used in this study was Bekenu series. The test crop in this study was Bario rice. Based on the soils' bulk density, plastic pots measuring $36 \mathrm{~cm}$ (height) x $30 \mathrm{~cm}$ (diameter) were filled with soil samples until the bulk density of this soil was attained. The soil in the plastic pots were flooded to $5 \mathrm{~cm}$ water above the soil surface and the rice seeds seeded at a rate equivalent to $25 \mathrm{~kg} / \mathrm{ha}$ (current seeding rate). It should be noted that for a good establishment, seeds were soaked for 24 hours in sacks. Planting involved two distinct operations - dibbling plant holes and sowing the seed. Dibbling was done with a staff or dibble - stick which was flared out slightly towards the base. The dibble - stick was dibbled into the soil and removed with a slight twisting action usually leaving well - formed planting holes $2 \mathrm{~cm}$ in diameter. The depth of the planting holes ranged from $2-4 \mathrm{~cm}$. Sowing was done by hand - broadcast and regulated by the number of seeds per throw. Seeds were sown directly in each planting hole. The planting holes were partially covered by loose soil from the surface so to allow quick emergence of the seeds. There were 12 seeds per pot.

Before the start of the experiment, the soil was analyzed for bulk density, $\mathrm{pH}$, total $\mathrm{N}$, exchangeable $\mathrm{K}$, $\mathrm{Mg}, \mathrm{Ca}$, total organic carbon, and cation exchange capacity (CEC). In this study, the coring method was used to obtain the bulk density of the soil ${ }^{[3]}$. The bulk density of the Bekenu series was $1.25 \mathrm{~g} / \mathrm{cm}^{3}$ and was typical of this soil series. To determine the $\mathrm{pH}$ in water and in $1 \mathrm{~N} \mathrm{KCl}$, a $\mathrm{pH}$ meter and $\mathrm{pH}$ buffer solutions (pH 4 and $\mathrm{pH} 7$ ) were used. Ten grams of soil samples were used in determining $\mathrm{pH}$ in water and $1 \mathrm{~N} \mathrm{KCl}$ (soil to water or $1 \mathrm{~N} \mathrm{KCl}$ of 1:2). The $\mathrm{pH}$ of the soil in water 
was 4.5 while that in $1 \mathrm{~N} \mathrm{KCl}$, was 3.5 and they are consistent with the $\mathrm{pH}$ of acid soils of Malaysia.

Total $\mathrm{N}$ was determined using micro-Kjeldahl method [4]. About 0.5 gram of soil, stem and roots were separately weighed into $50 \mathrm{~mL}$ Kjeldahl digestion tubes and treated with $5 \mathrm{~mL}$ concentrated sulphuric acid and one tablet of Kjeldahl catalyst (mixture of high selenium and sodium sulphate anhydrous) put in each tube. The samples were shaken and allowed to equilibrate for 30 minutes after which they were digested on a digestion block in a fume chamber. The samples were initially heated at $180{ }^{\circ} \mathrm{C}$ for 1 hour and then to $320{ }^{\circ} \mathrm{C}$ for 5 hours until samples became colourless, and they were then allowed to cool down. Afterwards, the samples were transferred into $50 \mathrm{~mL}$ volumetric flasks, diluted to volume using distilled water, and then filtered through Whatman filter paper number 2 . Ten $\mathrm{mL}$ of the filtrates were distilled with 10 $\mathrm{mL}$ of $40 \% \mathrm{NaOH}$ and the ammonium collected into $50 \mathrm{~mL}$ Erlenmeyer flask containing $10 \mathrm{~mL}$ of $2 \%$ boric acid-indicator mixture (bromocresol green-methyl red). Total $\mathrm{N}$ was determined by titrating the distillates with $0.01 \mathrm{M} \mathrm{HCl}$. The total was found to be $0.25 \%$ and typical of Bekenu series.

The double acid method [3] was used to extract the exchangeable $\mathrm{K}, \mathrm{Ca}$, and $\mathrm{Mg}$ in soil. Forty $\mathrm{mL}$ of 0.05 $\mathrm{M} \mathrm{HCl}: 0.025 \mathrm{M} \mathrm{H}_{2} \mathrm{SO}_{4}$ and another $40 \mathrm{~mL}$ of distilled water were separately added to $10 \mathrm{~g}$ of soil samples in plastic vials. The samples in the plastic vials were shaken for 10 minutes in an orbital shaker at $180 \mathrm{rpm}$. The samples were then filtered into new sets of plastic vials and filtered using Whatman paper number 2 . The solutions were then analyzed for the exchangeable K, $\mathrm{Ca}$, and $\mathrm{Mg}$ using the Atomic Absorption Spectrophotometry (AAS) and their concentrations were $6.82,6.54$, and $35.48 \mathrm{ppm}$. The $\mathrm{K}$ and $\mathrm{Ca}$ contents were typical of Bekenu series but that of $\mathrm{Mg}$ looks high.

Dry ashing (single dry ashing) ${ }^{[5]}$ was adopted for the extraction of $\mathrm{K}, \mathrm{Ca}, \mathrm{Mg}$, and $\mathrm{Na}$ in the plant tissues. Some samples of stem and roots were initially oven dried for 24 hours at a temperature of $60{ }^{\circ} \mathrm{C}$ after which they were cooled in a desicator and $0.5 \mathrm{~g}$ weighed into crucibles and placed in a muffle furnace and initially ashed at $300{ }^{\circ} \mathrm{C}$ for 1 hour. The temperature was raised to $520{ }^{\circ} \mathrm{C}$ for 5 hours. Few drops of distilled water were added to the samples, followed by $2 \mathrm{~mL}$ concentrated $\mathrm{HCl}$. Samples were evaporated to dryness in a fume chamber. Ten $\mathrm{mL}$ of $20 \% \mathrm{HNO}_{3}$ was added to the samples and heated on a hot plate in a fume chamber for 1 hour. The samples were filtered through Whatman filter paper number 2 into $100 \mathrm{~mL}$ volumetric flasks, and diluted to volume. The filtrates were analyzed for $\mathrm{K}, \mathrm{Ca}, \mathrm{Mg}$, and $\mathrm{Na}$ using AAS.

Cation exchange capacity of the soil samples was determined using the ammonium acetate (leaching) method $^{[5] .}$ Ten gram of each soil samples were weighed into leaching tubes covered with broth at the base and Whatman filter paper number 2 at both ends. The soil samples were leached with $1 \mathrm{M} \mathrm{NH}_{4} \mathrm{OAc}$ for 6 hours. The samples were then washed with $95 \%$ of ethanol and the ethanol discarded after collection. The soils were then leached with $100 \mathrm{~mL}$ of $0.1 \mathrm{M} \mathrm{K}_{2} \mathrm{SO}_{4}$ and the leachate collected in $100 \mathrm{~mL}$ volumetric and made up to volume. Ten $\mathrm{mL}$ of the samples were pipetted into distillation apparatus and $10 \mathrm{~mL}$ of $40 \% \mathrm{NaOH}$ added. The distillates were distilled and collected in $10 \mathrm{~mL}$ of $2 \%$ boric acid-indicator solution until $50 \mathrm{~mL}$ conical flask containing the distillate was twice the original volume $(20 \mathrm{~mL})$. The colour changed from purple to green during distillation. The distillates were then titrated with $0.01 \mathrm{M} \mathrm{HCl}$ until the colour changed from green to purple (end point). The CEC was $10.7 \mathrm{cmol} / \mathrm{kg}$ soil and typical of Bekenu series.

The fertilizer rate (Table 1) of $50 \mathrm{~N} \mathrm{~kg} / \mathrm{ha}, 40 \mathrm{P}$ $\mathrm{kg} / \mathrm{ha}$ and $30 \mathrm{~K} \mathrm{~kg} / \mathrm{ha}$ for the Bario rice variety was followed (recommendation of Semengok Agriculture Research Centre, Kuching, Malaysia). The fertilizers used were urea $(46 \% \mathrm{~N})$, Christmas Island Rock Phosphate $\left(36 \% \mathrm{P}_{2} \mathrm{O}_{5}\right)$ and Muriate of Potash $(60 \%$ $\mathrm{K}_{2} \mathrm{O}$ ).

Table 1: Split fertilizer application

\begin{tabular}{cc}
\hline Application & Days after seeding \\
\hline $1^{\text {st }}$ application $(1 / 3)$ & 20 \\
$2^{\text {nd }}$ application $(1 / 3)$ & 45 \\
$3^{\text {rd }}$ application $(1 / 3)$ & 75 \\
\hline
\end{tabular}

Table 2: Effect of fertilized (T1) and unfertilized (T0) conditions on CEC and $\mathrm{pH}$

\begin{tabular}{ccc}
\hline & Treatment & Value \\
\hline (a) & $\mathrm{CEC} \mathrm{(cmol/kg)} \mathrm{(T0)}$ & $11.56^{\mathrm{a}}$ \\
& $(\mathrm{T} 1)$ & $12.56^{\mathrm{a}}$ \\
(b) & $\mathrm{pH}$ in $\mathrm{KCl}$ & \\
& $(\mathrm{T} 1)$ & $4.18^{\mathrm{b}}$ \\
(c) & $\mathrm{pH}$ in Water & \\
& (T1) & $4.99^{\mathrm{b}}$ \\
\hline
\end{tabular}

Note: Same alphabet within column indicates insignificant difference between treatment means using independent $t$-test at $\mathrm{p} \leq 0.05$. 
Am. J. Agri. \& Biol. Sci., 2 (2): 99-105, 2007

Table 3: Total $\mathrm{N}$, exchangeable $\mathrm{K}, \mathrm{Ca}, \mathrm{Na}$, and $\mathrm{Mg}$ in soil under fertilized and unfertilized conditions

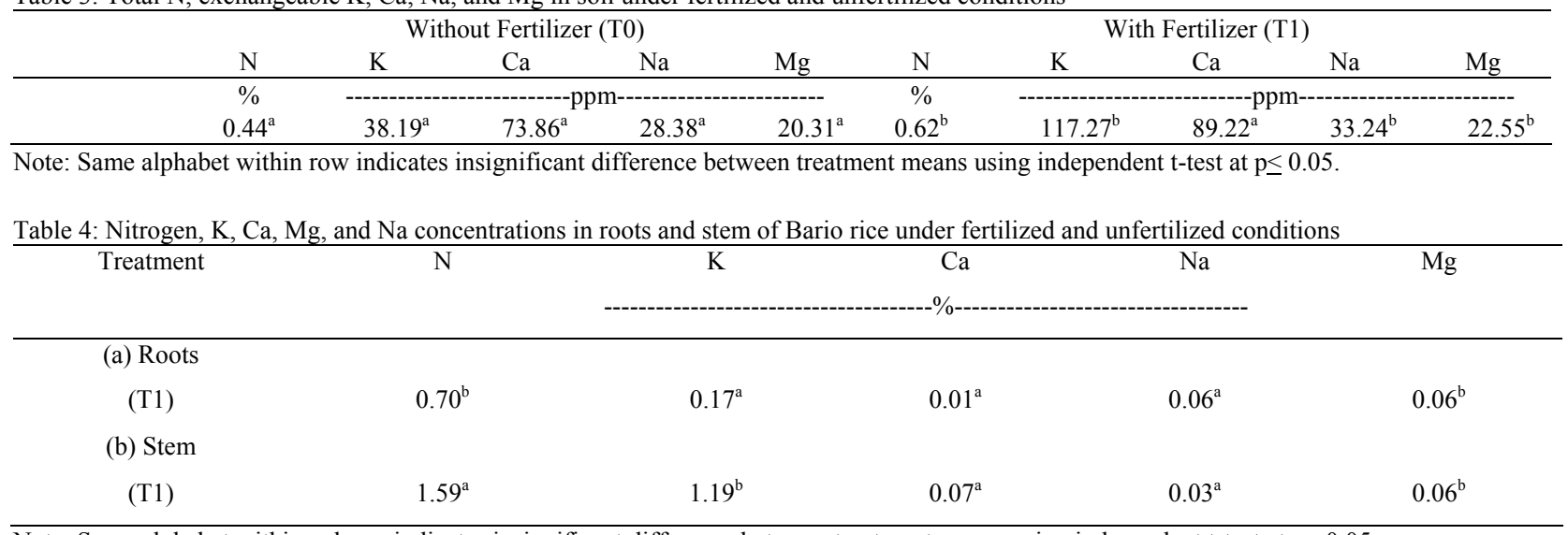

Note: Same alphabet within column indicates insignificant difference between treatment means using independent $t$-test at $\mathrm{p} \leq 0.05$.

Table 5: Dry weight (DW), N, K, Ca, Mg, and Na uptake in roots and stem under fertilized and unfertilized conditions

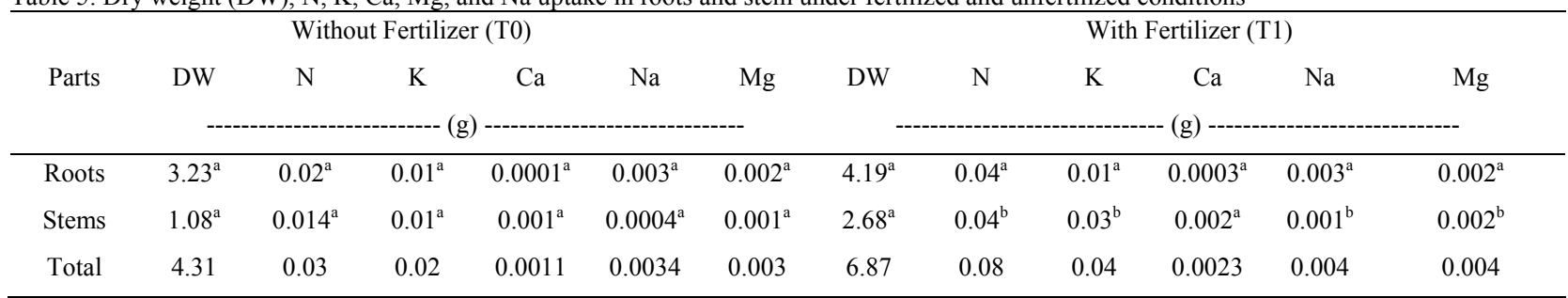

Note: Same alphabet within row indicates insignificant difference between treatment means using independent $\mathrm{t}$-test at $\mathrm{p} \leq 0.05$.

Table 6: Nitrogen and K use efficiency in roots and stem of Bario rice

\begin{tabular}{ccc}
\hline Treatments & N & K \\
& --1.466 & 0.067 \\
\hline Roots & 5.437 & 4.167 \\
Stem & 9.903 & 4.234 \\
Total &
\end{tabular}

The plants were monitored for 65 days. After 65 days, soil samples were taken and analyzed for $\mathrm{N}, \mathrm{K}, \mathrm{Ca}, \mathrm{Mg}$, $\mathrm{Na}$, organic matter, $\mathrm{pH}$, and $\mathrm{CEC}$. Nitrogen, and $\mathrm{K}$ uptake and yield of the rice variety were determined. At 65 days after planting, the plants were harvested and partitioned into roots and stem. Standard procedures were used to dry these parts, and determination of their dry weight.

The concentrations of $\mathrm{N}$ and $\mathrm{K}$ in the plant parts multiplied by their dry matter gave the amount of $\mathrm{N}$ and $\mathrm{K}$ taken up by the plant parts. Nitrogen and $\mathrm{K}$ useefficiency were calculated using the subtraction method [6]. Nitrogen and K use efficiency was calculated using the formula:

\section{$\% \mathrm{~N}$ use efficiency $=$ \\ (Total $\mathrm{N}$ uptake in fertilized plots - Total $\mathrm{N}$ uptake in unfertilized plots $\mathrm{x} 00 \%$ Total amount of $\mathrm{N}$ fertilizer applied}

The experimental design was completely randomized design with nine replications. Data was analyzed statistically by independent and paired t-test to detect treatment effect. The statistical software used was the Statistical Analysis System (SAS) version 9.1 [7].

\section{RESULTS AND DISCUSSION}

The CEC and $\mathrm{pH}$ after harvest under fertilized and unfertilized conditions are presented in Table 2. The treatment mean of the CEC for without fertilizer (T0) was $11.56 \mathrm{cmol}(+) / \mathrm{kg}$ while that of with fertilizer (T1) was $12.56 \mathrm{cmol}(+) / \mathrm{kg}$. The treatment mean of T0 for $\mathrm{pH}$ in $\mathrm{KCl}$, was 3.98 while that of $\mathrm{T} 1$ was 4.18 . As for the treatment mean of $\mathrm{T} 0$ for $\mathrm{pH}$ in water, it was 4.82 and that of $\mathrm{T} 1$ was 4.99. Regardless of treatment, $\mathrm{CEC}$ and $\mathrm{pH}$ values were typical of Bekenu series. The outcome of the statistical comparisons of treatment means (Table 2) were: (i) CEC in soil for T0 and CEC in soil for $\mathrm{T} 1$ - no significant difference, (ii) $\mathrm{pH}$ in $\mathrm{KCl}$ 
for $\mathrm{T} 0$ and $\mathrm{pH}$ in $\mathrm{KCl}$ for $\mathrm{T} 1$ - significant difference, and (iii) $\mathrm{pH}$ in water for $\mathrm{T} 0$ and $\mathrm{pH}$ in water for $\mathrm{T} 1-$ significant difference.

The total $\mathrm{N}$, exchangeable $\mathrm{K}, \mathrm{Ca}, \mathrm{Na}$, and $\mathrm{Mg}$ in soil with and without fertilization are shown in Table 3. The treatment mean of $\mathrm{T} 0$ for total $\mathrm{N}$ was $0.44 \%$ and that of T1 was $0.62 \%$. The treatment means of T0 for $\mathrm{K}, \mathrm{Ca}, \mathrm{Na}$, and $\mathrm{Mg}$ were $38.19,73.86,28.38$, and 20.31 ppm respectively while those of $\mathrm{T} 1$ for $\mathrm{K}, \mathrm{Ca}, \mathrm{Na}$, and $\mathrm{Mg}$ were 117.27, 89.22, 33.24, and $22.55 \mathrm{ppm}$ respectively. The outcome of the statistical comparisons of treatment means (Table 3) were: (i) Total $\mathrm{N}$ in soil for T0 and T1 - significant increase, (ii) Exchangeable $\mathrm{K}$ in soil for $\mathrm{T} 0$ and $\mathrm{T} 1$ - significant increase, (iii) Exchangeable $\mathrm{Ca}$ in soil for $\mathrm{T} 0$ and $\mathrm{T} 1$ - no significant increase, (iv) Exchangeable $\mathrm{Na}$ in soil for $\mathrm{T} 0$ and $\mathrm{T} 1-$ significant increase, and (v) Exchangeable $\mathrm{Mg}$ in soil for $\mathrm{T} 0$ and $\mathrm{T} 1$ - significant increase.

The $\mathrm{N}, \mathrm{K}, \mathrm{Ca}, \mathrm{Mg}$, and $\mathrm{Na}$ concentrations in Bario rice roots and stem unfertilized and fertilized conditions are presented in Table 4. For roots, the treatment means of $\mathrm{T} 0$ for $\mathrm{N}, \mathrm{K}, \mathrm{Ca}, \mathrm{Na}$, and $\mathrm{Mg}$ were $0.52,0.15,0.004$, 0.08 , and $0.05 \%$ respectively while that of $\mathrm{T} 1$ for $\mathrm{N}, \mathrm{K}$, $\mathrm{Ca}, \mathrm{Na}$, and $\mathrm{Mg}$ were $0.70,0.17,0.01,0.06$, and $0.06 \%$ respectively. As for stem, the treatment means of T0 for $\mathrm{N}, \mathrm{K}, \mathrm{Ca}, \mathrm{Na}$, and $\mathrm{Mg}$ were $1.34,0.74,0.11,0.04$, and $0.05 \%$ respectively while that of $\mathrm{T} 1$ for $\mathrm{N}, \mathrm{K}, \mathrm{Ca}, \mathrm{Na}$, and $\mathrm{Mg}$ were $1.59,1.19,0.07,0.03$, and $0.06 \%$ respectively. The outcome of the statistical comparison of treatment means (Table 4) were: (i) Nutrient concentrations in roots for $\mathrm{T} 0$ and $\mathrm{T} 1$ conditions - no significant increase in $\mathrm{K}, \mathrm{Ca}$, and $\mathrm{Na}$ but significant increase for $\mathrm{N}$ and $\mathrm{Mg}$, and (ii) Nutrient concentrations in stem for $\mathrm{T} 0$ and $\mathrm{T} 1$ conditions - no significant increase in $\mathrm{N}, \mathrm{Ca}$, and $\mathrm{Na}$ but significant increase for $\mathrm{K}$ and $\mathrm{Mg}$.

The average height and panicles of Bario rice per pot from Day 20 to Day 60 are presented in Figures 1 and 2. The average height of paddy for T0 in ascending order (Day 20 to Day 60) were 33.61, 35.67, 37.61, $39.33,41.61$, and $44.44 \mathrm{~cm}$ while those of $\mathrm{T} 1$ in ascending order (Day 20 to Day 60) were 33.94, 37.56, $39.94,43.22,44.11$, and $56.89 \mathrm{~cm}$. The average numbers of panicles of the paddy for T0 from Day 20 to Day 60 were $4,4,4,4.38,4.38$, and 4.88 . The average numbers of panicles of the paddy for T1 from Day 20 to Day 60 were 4, 4, 4.44, 5.05, 5.29, and 7.11. The results of the comparison of treatment means were: (i) Height of Bario rice for $\mathrm{T} 0$ and that of $\mathrm{T} 1$ - no significant increase on Day 20 and Day 48 and significant increase on Days 27, 34, 41, and 60, and (ii) Number of panicles of Bario rice for $\mathrm{T} 0$ and that of $\mathrm{T} 1$ - no significant increase from Day 20 to Day 34 and significant increase from Day 41 to Day 60.

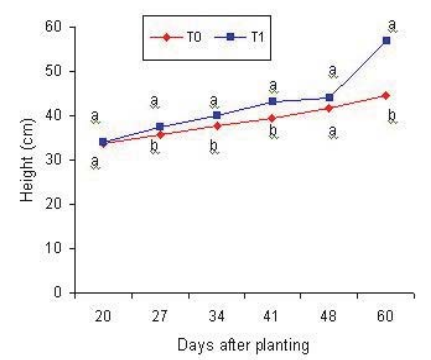

Note: Same alphabet indicates no significant difference between treatment means using independent $t$-test at $\mathrm{p} \leq 0.05$.

Fig. 1: Effect of fertilized and unfertilized conditions on Barice rice height with time

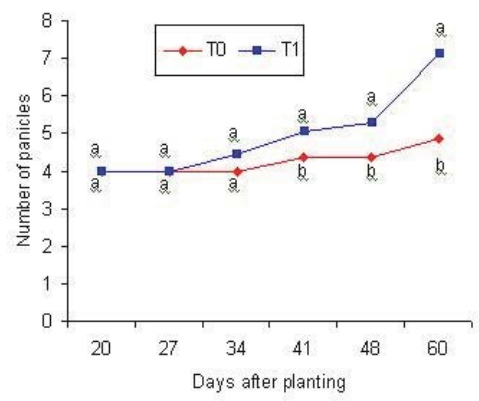

Note: Same alphabet indicates no significant difference between treatment means using paired t-test at $\mathrm{p} \leq 0.05$.

Fig. 2: Effect of fertilized and unfertilized conditions on Barice rice panicles with time

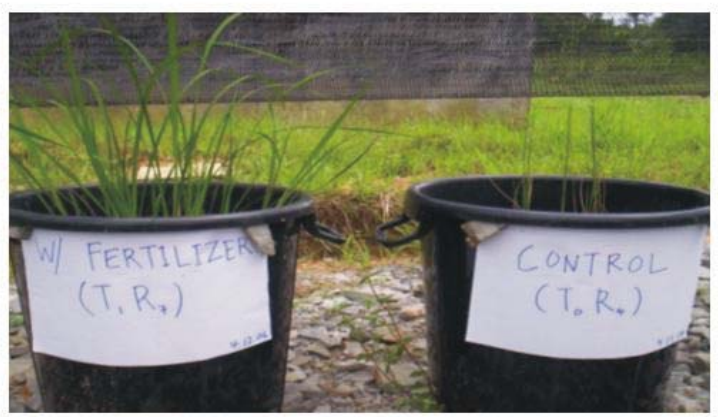

Fig. 3: Growth of fertilized (T1) and unfertilized (T0) Bario rice

Fig. 1 shows an increase in the height of Bario rice from Day 20 to Day 60 for both treatments (T0 and T1). Also noticeable is that the plant height of T1 was higher 
than T0 starting from Day 27 until Day 60. As for Fig. 2 , it shows a constant number of panicles from Day 20 to Day 34 for $\mathrm{T} 0$ and then gradually increased with time from Day 34 to Day 60 while for T1, a constant number of panicles from Day 20 to Day 27 followed by a gradual increased with time from Day 27 to Day 48 and a sharp increased from Day 48 to Day 60 can be seen in Fig. 2. Fig. 3 shows the height and number of panicles of the fertilized and unfertilized Bario rice. The growth of the fertilized plants was clearly better than those of the unfertilized plants.

The dry weight of Bario rice roots and stem for $\mathrm{T} 0$ and $\mathrm{T} 1$ are presented in Table 5. The total dry weight (roots and stem) of T0 and $\mathrm{T} 1$ were $4.31 \mathrm{~g}$ and $6.87 \mathrm{~g}$ respectively. In terms of parts, the dry weight production (roots and stem) regardless of treatments was not significant. The total nutrients uptake for T0 and $\mathrm{T} 1$ respectively were: $\mathrm{N}=0.03 \mathrm{~g}$ and $0.08 \mathrm{~g}$; $\mathrm{K}=$ $0.02 \mathrm{~g}$ and $0.04 \mathrm{~g} ; \mathrm{Ca}=0.001 \mathrm{~g}$ and $0.002 \mathrm{~g} ; \mathrm{Na}=$ $0.003 \mathrm{~g}$ and $0.004 \mathrm{~g}$; and $\mathrm{Mg}=0.003 \mathrm{~g}$ and $0.004 \mathrm{~g}$. Irrespective of treatment, $\mathrm{K}$ and $\mathrm{Ca}$ distribution was higher in the stems than in the roots. In the case of $\mathrm{Na}$, the distribution was higher in roots than in stem. As for $\mathrm{N}$, the distribution was higher in roots than in stem for T0. In the case of $\mathrm{T} 1$, it was higher in stem than in roots. For $\mathrm{Mg}$, the distribution was higher in roots than stem for $\mathrm{T} 0$ while for $\mathrm{T} 1$, the distribution in roots and stem was similar. The results of the statistical comparisons of treatment means (Table 5) were: (i) T0 and T1 - no significant increase in dry weight (DW), N, $\mathrm{K}, \mathrm{Ca}, \mathrm{Na}$, and $\mathrm{Mg}$ uptake in roots, and (ii) No significant increase in dry weight (DW), and Ca uptake but significant increase in $\mathrm{N}, \mathrm{K}, \mathrm{Na}$, and $\mathrm{Mg}$ uptake in stem.

The results of the $\mathrm{N}$ and $\mathrm{K}$ use efficiency in roots and stem are shown in Table 6. For roots, the percentage for $\mathrm{N}$ was 4.466 and $\mathrm{K}$ was 0.067 while for stem, the percentage for $\mathrm{N}$ was 5.437 and $\mathrm{K}$ was 4.167 . The overall $\mathrm{N}$ and $\mathrm{K}$ use efficiencies of the Bario rice were $9.90 \%$ and $4.23 \%$ respectively.

The insignificant difference between the CEC of $\mathrm{T} 0$ and $\mathrm{T} 1$ at harvest suggests that fertilization did not affect the exchange property of the soil within the time frame of this study (Table 2). This observation was expected as organic matter that usually affects soil CEC was not included in this study and no leaf decomposition in the experimental pots as the plant grew was observed. However, the $\mathrm{pH}$ of $\mathrm{T} 1$ in both water and $\mathrm{KCl}$ were greater than those of $\mathrm{T0}$ (Table 2) probably due to the addition of fertilizers particularly urea which is known for increasing soil $\mathrm{pH}$ rapidly at the soil microsites [8]. Anhydrous ammonia, urea, diammonium phosphate, and nitrogen solutions, when first applied, greatly but temporarily increase soil $\mathrm{pH}$ in the zone of application ${ }^{[9]}$.

The significant increase in soil $\mathrm{N}, \mathrm{K}, \mathrm{Mg}$, and $\mathrm{Na}$ concentrations (Table 3) for the fertilized condition (T1) could be attributed to the addition of urea and $\mathrm{KCl}$ (MOP). This finding was consistent with that of Nand ${ }^{[10]}$ who observed that the patterns of the availability of $\mathrm{N}$ and $\mathrm{K}$ were affected by continuous fertilizer use.

The general insignificant difference in nutrient concentrations in roots and stem (Table 4) may be ascribed to dilution effect ${ }^{[11,12] .}$ Lack of significant effect on $\mathrm{N}$ uptake may be partly due to ammonia volatilization and denitrification under reduced condition or under submerged conditions of rice ${ }^{[13,14]}$. Upon application, urea-N changes rapidly to $\mathrm{NH}_{4}{ }^{-} \mathrm{N}$ and therefore is readily available to plants on application to the soil. Urea presents another problem, in that when it is surface-applied, significant quantities of nitrogen as ammonia may be lost through volatilization which cause low $\mathrm{N}$ uptake in plants ${ }^{[13,14]}$. This occurs because the urea dissolves, be in contact with the soil for conversion to volatile nitrogen, and easily escapes to the atmosphere due to its proximity to the soil surface $[13,14]$.

Although there was general increase in plant height and number of panicles with time irrespective treatments, the significant increase in these variables with time (Figs. 1 to 3 ) under the fertilized condition (T1) compared with the unfertilized condition (T0) to fertilization with time could be partly associated with $\mathrm{K}$ and $\mathrm{N}$ fertilization.

There was no significant difference between root dry weight and $\mathrm{N}, \mathrm{K}, \mathrm{Ca}, \mathrm{Na}$, and $\mathrm{Mg}$ under $\mathrm{T} 0$ and $\mathrm{T} 1$. In the case of stem, the difference in dry weight of the treatment was not significant but in terms of uptake, except for $\mathrm{Ca}, \mathrm{N}, \mathrm{K}, \mathrm{Na}$, and $\mathrm{Mg}$ uptake under $\mathrm{T} 1$ were statistically higher than T0. Obviously, addition of urea and $\mathrm{KCl}$ fertilizers explains the higher uptake of $\mathrm{N}$ and $\mathrm{K}$ in the stem under the fertilized condition compared to the unfertilized condition. Different rates of $\mathrm{N}$ and $\mathrm{K}$ applied to rice plant under greenhouse conditions significantly increased the uptake of macro and micronutrients in rice grain ${ }^{[15] \text {. }}$

Regardless of treatment, the low percentages of $\mathrm{N}$ and $\mathrm{K}$ indicate that the $\mathrm{N}$ and $\mathrm{K}$ nutrient uptake by the plants even though significant in stem, the general nutrient use by Bario rice on Bekenu series was low or inefficient. The low fertility status and the terrain on which these soils occur could be some of the limiting factors for the use of these soils. However, with proper addition of organic fertilizers as supplement of 
inorganic fertilizers and soil conservation measures, the $\mathrm{N}$ and $\mathrm{K}$ use efficiency may be improved.

\section{CONCLUSION}

Application of $\mathrm{N}$ and $\mathrm{K}$ fertilizers significantly increased $\mathrm{N}, \mathrm{K}, \mathrm{Mg}$, and $\mathrm{Na}$ accumulation in Bekenu series soil. Roots and stem dry weight of Bario rice showed no significant difference under $\mathrm{T} 0$ and $\mathrm{T} 1$. Addition urea and MOP had significant effect on $\mathrm{N}$ and $\mathrm{K}$ uptake in stem. However, the $\mathrm{N}$ and $\mathrm{K}$ use-efficiency ( $10 \%$ for $\mathrm{N}$ and $4 \%$ for $\mathrm{K}$ ) of Bario rice on Bekenu series was low.

As the results showed inefficient nutrient use, series of trials on Bekenu series on the interaction between inorganic and organic fertilizers (e.g. compost) should be carried out. This is essential because Bario rice seems to grow well under organic fertilization. Probably supplementing inorganic fertilizers with organic fertilizers may help in good growth and development of Bario rice on Bekenu series since it may be difficult and expensive to mimic the climatic conditions under which Bario rice grows well.

\section{REFERENCES}

1. Brohi, 1998. Effect of nitrogen and phosphorus fertilization on the yield and nutrient tatus of rice crop grown on artificial siltation soil from the Kelkit river. Turkey Journal of Agriculture and Forestry, 22: 585-592.

2. Paramanathan, S., 2000. Soils of Malaysia: Their characteristics and Identification. Volume 1. Akademi Sains Malaysia, pp: 121-384.

3. Tan, K. H., 1996. Soil sampling preparation, and analysis. Marcel Dekker, Inc., pp: 170-174.

4. Bremner, J.M., 1965. Total nitrogen. American Society of Agronomy. Monograph, 9: 1149-1178.

5. Cottenie, A., 1980. Soil testing and plant testing as a basis of fertilizer recommendation. FAO Soils Bulletin, 38: 70-73.

6. Pomares-Gracia, F. and P.F. Pratt, 1987. Recovery of $15 \mathrm{~N}$-labelled fertilizer from manured and sludged-amended soils. Soil Science Society of American Journal, 42: 717-720.
7. SAS 2007. SAS Enterprise Guide. SAS Institute Inc, pp: 3-15.

8. Ahmed, O.H., H. Aminuddin, and M.H.A. Husni, 2006. Reducing ammonia loss from urea and improving soil-exchangeable ammonium retention through mixing triple superphosphate, humic acid and zeolite. Soil and Management, 22: 315-319.

9. Wilson, C. E., N. A. Slaton, R. J. Norman, and D. M. Miller, 2001. Efficient use of fertilizer. In: Rice Production Handbook (ed N. A. Slaton) pp. 51-74 Univ. Ark. Coop. Ext. Serv. Publ., USA.

10. Nand, R., 2000. Long-term Effects of Fertilizers on Rice-Wheat-Cowpea Productivity and Soil Properties in a Mollisols. In: Long-term Soil Fertility Experiments in Rice-Wheat Cropping Systems (eds I. P., Abrol, K. E. Bronson, J. M. Duxbury and R. K Gupta) pp. 50-55. Rice-Wheat Consortium for the Indo-Gangetic Plains, New Delhi, India

11. Marschner, H., 1995. Mineral nutrition of higher plants. $2^{\text {nd }}$ edn. Academic Press Limited, pp: 483507.

12. Mengel, K. and E. A. Kirkby, 1996. Principles of Plant Nutrition. $4^{\text {th }}$ edn. New Delhi Panina Publishing Corporation, pp: 147-149.

13. Prasertsak, P., J. R. Freney, P. G, Saffiga, O. T. Denmead and B.G. Prove, 2001. Fate of urea nitrogen applied to a banana crop in the wet tropics of Queensland. Nutrient Cycling in Agroecosystems, 59: 65-73.

14. Cai, G. X., D. L. Chen, H. Ding, A. Pacholski, X. H. Fan and Z. L Zhu, 2002. Nitrogen losses from fertilizers applied to maize, wheat and rice in the North China Plan. Nutrient Cycling in Agroecosystems, 63: 187-195.

16. Rafey, A., P. A. Khan, and V. C. Srivastava, 1989. Effect of $\mathrm{N}$ on growth, yield and nutrient uptake of uplant rice. Indian Journal of Agronomy, 34(1): 133-135. 